\title{
神戸ポートアイランド
}

\section{新しい“海の文化都市” の創造}

\author{
大屋 昌 弘*
}

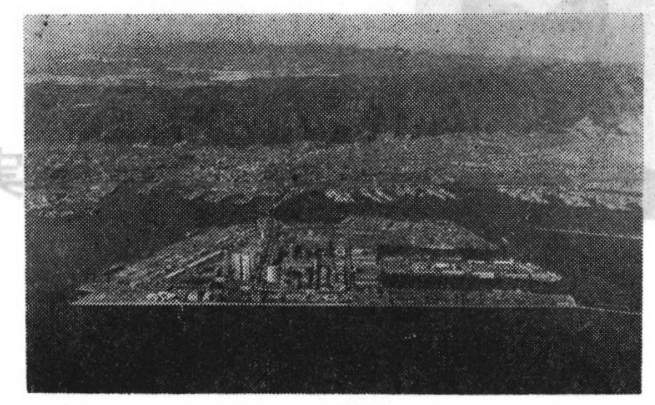

図 1 ポートアイランド完成予想図（合成写真）

\section{1. は じめに}

神戸港の中央に, 15年の歳月をかけて生まれた新しい 「海の文化都市・ポートアイランド」.この中心街区にラン ドマークとしてそそり立つ神戸ポートピアホテルからのな がめはすばらしい，北側に六甲連山が東西に連なり，その 前面のゆるやかな斜面に市街地や港がひろがり，南側は大 阪湾沿いの大阪，堺，和歌山はもとより，淡路島まで一望 のもとに見渡せる、夜は街に灯がともり、なお一層すばら しい夜景が目の前にひろがり，自然と人工の調和を感じさ せる.

このポートアイランドの完成を記念して，3月20日から 9 月15日子で, 神戸ポートアイランド博覧会（ポートピア 81）を開催し，全国からまた外国からも大勢の拈客さんが つめかけてたいへんにぎわいを見せている。こうして神戸 を訪れた人々が, 未来都市をめざして造ったポートアイラ ンドを, また神戸を広く知ってもららことを期待してい る.

\section{2. 事 業の 概 要}

ポートアイランドは, 神戸市の都心である三の宮から南 へ $3 \mathrm{~km}$ の海上に浮かぶ南北約 $2 \mathrm{~km}$, 東西約 $3 \mathrm{~km}$, 埋立 て面積 436 ha で, 甲子園球場が 110 もいるほど大きい。

みなと街神戸の沖合いに，21世紀の未来都市を築くとい ら壮大な夢を、税金をほとんど使わないで，マルク債など の借入金により2,300億円の巨費を投じ，「山，海へ行く」 の言葉どおり 8,000 万 $\mathrm{m}^{3}$ 分の山を削り， 跡地はニュータ ウンをつくりこの土砂を幅 $2 \mathrm{~m}$ の空中ベルトコンベヤー で海岸まで運び, 海のダンプトラックと呼ばれるプッンャ ーバージ (押船) で海を埋め立てた。この間最新の技術開 発を数多く行ない，41年の着工以来15年を費してこの56年 2 月に埋め立てが完了した.

同時に,このポートアイランドの中心部と三の宮を約 10 分で結ぶ, わが国で初めての新交通システム・ポートライ ナーが開通し, 営業運転を始めた。

$\dagger$ Creation of a New "Cultural City on the Sea" on Kobe Port-Island

* 神戸市開発局計画課 Masahiro Oya 紹介者 専門会員 吉川孝次郎

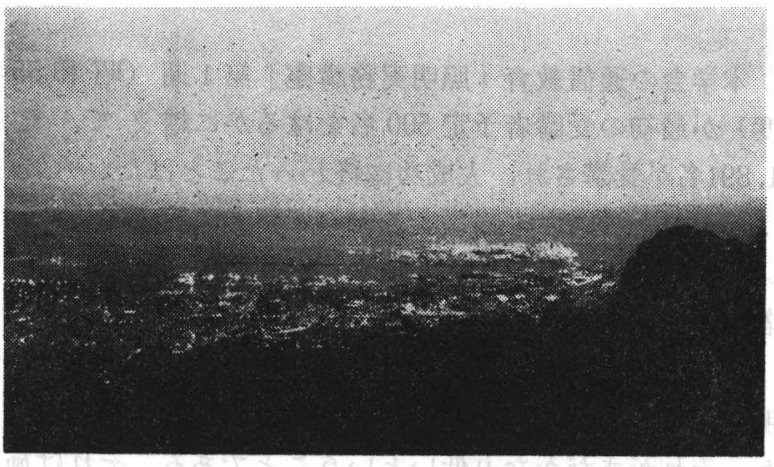

図 2 摩耶山からの展望

\section{3. 土地利用計画}

将来人口 2 万人の「住み, 働き, 覟い, 学び, 集う」と いら都市のあらゆる機能を備光, 経済, 文化, 情報, 国際 交流の中核となる，世界で初めての「海の文化都市」の創 造をめざしている.これはポートアイランドが, コンテナ で代表される外国貿易における物の流れの拠点であると同 時に, 都市中心部に近い立地を生かし, 神戸のもつ特性を 生かした「緑あふれる国際色豊かな街」を創造し, これら の機能を有機的に調和・融合させ，人間中心の街を実現し ようとする新しい試みである.

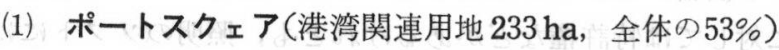
コンテナ埠頭 12 バースライナー（一般外航定期船）埠頭 15バース, およびその背後の港湾機能用地からなってい る. コンテナヤードは 45年以来嫁動して和り, 現在コンテ ナー貨物取扱量は世界一である.

(2) インタナショナルスクェア（32ha）

神戸の国際的, 近代的感覚を生かし, 神戸らしさに満ち た文化を育成する拠点として，また世界の空口としての国 際的な取引さと交歓の場を提供するとともに，市民が集 い, 語らい, 憩う場を提供することをめざしている.

\section{(a) コンベンション（国際会議・見本市）都市施設}

国内・国外の会議や見本市を誘致し，新しい都市機能を 推進するために, 神戸国際会議場, 神戸国際展示場, 貿易 促進センター, 神戸ポートピアホテル，光の他関連施設と. して，集会や催し物がでさるスポーツセンターなど，最新 設備をもった大型施設がすでに建設されている. 


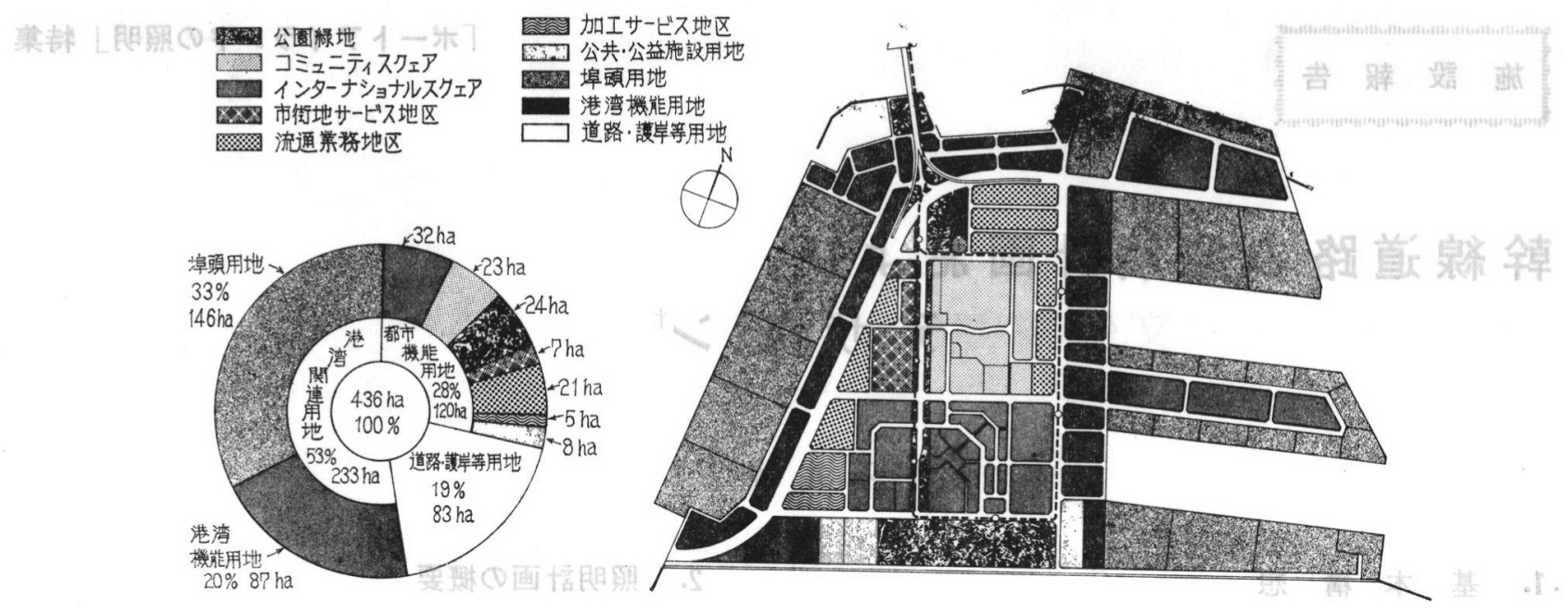

図 3 土地利用計画図

\section{(b) ファッション系業務施設}

知識集約型産業であるファッション関連企業を育成する ために，またファッション都市神戸を実現するため，衣 服, 真珠, 家具などの幅広いファッション系企業の集積を 計り,ファッション街区とする、街づくりは, 人間性あふ れる快適な街ら゙くりのモデル街区として計画している.

\section{(c) 余暇関連施設}

余㗇時間の増大と有意義な活用のために, スポーツセン ター, 科学博物館, レジャーランド, 文化教室・専修学校 などを併存した民間住宅が建設され，計画されている。

（d）その他，都心型の新しいひろばとして市民広場，エ キゾチックなふん囲気を楽しむショッピング・レジャーセ ンターのエキゾチックタウンなど, 新しいニニークな構想 のもとに各種施設計画がなされている.

(3) コミュニティスクェア（23ha）

海と山が見兄, 緑あふれる, 都心炘い, 約 6,500 戸， 人口 2 万人の高層高密度住宅街である.

\section{（4）市街地サービス地区（7 ha）}

ポートアイランド, 特よび既成市街地のための各種サー ビス施設である市民病院, 郵便局, 電話局, 生活科学研究 所などが配置されている。

\section{(5) マリンパーク (24ha)}

これらの地区を有機的に結びつけ，市民が海や港に親し みをるつよら北から南へ緑地を通し，北・中・南公園の大 規模な公園緑地を整備している。

\section{4. 新しい都市空間の環境・景観形成}

ポートアイランドの中心地区（都市機能用地）は，道 路, 公園などの公共空間から私空間（敷地内空間）まで都 市の環境と景観を総体的に捉え，土地利用計画などを考虑 して必要な措置を講じている。

その基本目標は，「国際感覚あ心和る，緑豊かな，若々
しいハイセンスな，明るい街」といらイメージで「神戸ら しさのある新しい街」を創造することとしている.

\section{（1）公共空間の環境・景観形成}

景観道路として, 都市軸であり緑地軸であるポートピア 大通りを含めて 5 本を設定し, 重点的に整備を行なう。

公園は，港と緑に親しむ公園としてそれぞれ特徵を持た せ，悡いと快い景観と魅力あるレクリェーションの場とな るよう配慮している.

屋外照明計画は，新しい街づくりにふさわしい照明環境 や演出を行ない，照明器具も新しいデザインとするため に, 洙石井幹子デザイン事務所に照明基本計画之照明器具 のデザインを依頼した.

その他サイン, ストリートファニチュア，植栽，舖装面 のペイブ. 歩道橋, 電話ボックスなどの景観要素について も全体の調和を基本にデザインしている.

\section{(2) 半公共空間の環境・景観形成}

ポートアイランドの都市空間の特徴は, 主要な道路空間 （公共空間）を軸として，公私両空間の緩衝帯 (半公共空 間一コモンスペースー道路境界線から $3 \mathrm{~m}$ なし $5 \mathrm{~m}$ の壁 面後退部分）を創出し，歩行者空間あるいは植栽帯として 整備し，新しい街並みを創造していることである.

へいも生けがきを原則とし，車の出入り口の位置も制限 している.

\section{（3）私空間の環境・景観形成}

神戸市が各事業者と土地譲渡契約を結ぶ際に，「良好な 環境・景観の形成および保全協定」を結び、この中でそれ ぞれの敷地が全体計画の中で占める役割に応じて，条件を 設定している.

具体的には隣地からの $2 \mathrm{~m}$ の壁面後退, 建物の主要面の 向き, 屋外広告物の規制, 点滅灯の禁止, 洗たく物の措置 などそついて定めている.

（受付 1980 年 6 月 6 日） 